\title{
Organotin compounds in marine sediment: Detection and concerns
}

\author{
Lofrano G. ${ }^{1}$, Nikolaou A. ${ }^{2}$, Libralato G. ${ }^{3,}{ }^{*}$ and Carotenuto M. ${ }^{1}$ \\ ${ }^{1}$ Department of Chemistry and Biology “A. Zambelli”, University of Salerno, via Giovanni Paolo II, 18284084 Fisciano, Salerno, Italy \\ 2Department of Marine Sciences, University of Aegean University Hill, GR-81100, Mytilene, Greece \\ ${ }^{3}$ Department of Biology, University of Naples Federico II, Complesso Universitario di Monte S. Angelo, Via Cinthia ed. 7, 80126 Naples, \\ Italy \\ Received: 04/05/2017, Accepted: 25/08/2017, Available online: 25/01/2018 \\ *to whom all correspondence should be addressed: e-mail: giovanni.libralato@unina.it
}

\begin{abstract}
The determination of organotin compounds (OTCS) in environmental matrices has been subject to great scientific attention during last years, as the accuracy and sensitivity of analytical methods need to be improved in order to be able to detect the compounds of interest in a complex matrix such as sediment. The European Union Water Framework Directive (2013/39/EU) sets very restrictive environmental quality standards for 45 priority substances and other pollutants, including OTCs. Therefore, it is necessary to develop analytical methods in compliance with the environmental quality standard (EQSs) proposed to protect the aquatic environment and human beings. So far various analytical procedures have been used, including gas chromatographic analyses. Most of these methods comprise different steps such as extraction, derivatisation, clean up and the use of several sophisticated instrumentations, as well. Among them the conversion of tributyltin into $\mathrm{Sn}$ to allow its determination by Atomic Absorption Spectrometry or Anodic Stripping Voltammetry (AVS) has also been attempted. A great number of studies have been performed on OTCs analysis in marine sediment. However, the only review available in literature discussing the upgrades of analytical methods is dated back to 1997. We reviewed the analytical procedures and discussed them comparatively in order to identify the current state-of-theart in OTCs detection. Finally, environmental concerns about OTCs were discussed.
\end{abstract}

Keywords: OTCs, TBT, antifouling paint, marine sediment, analytical methods

\section{Introduction}

Organotin compounds (OTCs) have been used extensively worldwide as biocides in marine antifouling paints. As a result, they have become one of the major categories of pollutants entering the marine environment and finally accumulating in sediment being characterized by high toxicity, high stability in the environment and high lipophilicity (Diez et al., 2005; Gomez-Ariza et al., 2006; Libralato et al., 2008, 2010; Mamindy-Pajany et al., 2010;
Lofrano et al., 2016a). Tributyltin compounds (TBT) occur at high concentrations in water, sediment, and biota associated with harbour locations whereas dibutyltin (DBT) and monobutyltin (MBT) contamination is believed to result from tributyltin degradation rather than from direct input. TBT can cause chronic and acute toxic effects to algae, zooplankton, molluscs, and some fish species even at very low concentrations. Moreover, Tributyltin (TBT) is associated to imposex phenomena (Fernandez et al., 2005). Triphenyltin (TPhT) is less toxic than TBT, but can also be of high risk to aquatic life. The high level of BT contamination and their adverse health effects resulted in the restriction of the use of tributyltin (TBT) in antifouling paints. As a result, BT levels in coastal environments have been decreasing worldwide (Sousa et al., 2007; Rato et al., 2009). However, high levels of BTs are still detected in a variety of aquatic organisms and are found in water and sediment from estuaries and harbours (Leung et al., 2006; Berto et al., 2007; Lofrano et al., 2016; Lofrano et al., 2017). Thus, the environmental occurrence and adverse health effects of BTs on marine organisms are still of concern.

The first regulatory actions and legislative management of tributyltin were adopted in France in 1982. The UK followed suit in 1985 (Terlizzi et al., 2001). However it was only with the AFS Convention, which was signed in 2003 but came in force only since January 2008, that any OTC was completely banned. The United Nations Environment Programme (UNEP) and Food and Agriculture Organization of the United Nations (FAO) added the pesticide TBT to a global trade "watch list" after the Rotterdam Convention in November 2008. Despite these bans, high concentrations of OTCs continue to be detected in marine sediment (Lofrano et al., 2016). Their widespread use has introduced high levels of contamination into the environment and raised concerns about their toxic effects on marine communities.

The scientific interest in the quality of marine sediment has increased remarkably in the past 30 years and especially in relation to application of the European Union Water Framework Directive (WFD 2000/60/EC). Since 1980, when 
the ecological impact of OT-based antifouling paints on marine biota became evident, the negative effects of such biocides have been studied with increasing intensity. Using the website www.sciencedirect.com as a research tool, in the period from 1980 to 2016 we found 1811 scientific papers dealing with marine sediment related to OTCs. According to Figure 1 literature studies significantly increased until 2000 as consequence of the severe restrictions on the use of TBT.

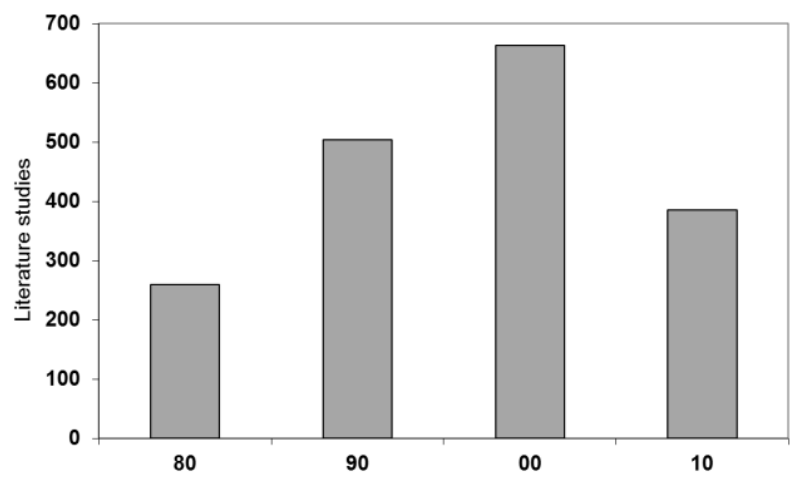

Figure 1. Distribution of literature studies on OTCs in the period from 1980 to 2016

To evaluate the environmental distribution and fate of these compounds and to determine the efficiency of legal provisions adopted by a number of countries, a variety of analytical methods have been developed for OT determination in the environment. (Ochsenkühn et al., 2001; Szpunar-Lobinska et al., 1995). However, the only review available in literature discussing the upgrading of analytical methods is dated 1997 (Abalos, 1997).

\section{OTCs: Sink, source, and final fate}

OTCs comprise a group of organo-metallic moieties characterized by the presence of one or more covalent bonds between atoms of tin (Sn) and one or more organic substituents (methyl, ethyl, butyl, propyl, phenyl). The physical and chemical properties of OTs vary widely, according to the number and type of organic and inorganic moieties bonded to the tin atom. The persistence and fate of OTs in the aquatic environment are functions of such factors as aqueous solubility and vapour pressure of the compound, adsorption to suspended matter and sediment, and abiotic and biotic methylation and demethylation. Water solubility typically range from 5 to $50 \mathrm{mg} \mathrm{L}^{-1}$ and are inversely proportional to the number and molecular weight of the organic groups attached to the tin atom (NRCC 1985). Most commercially used OTs have low mobility in aquatic environments as a result of low aqueous solubility, low vapour pressure, and a high affinity for aquatic sediment (Blundin and Chapman, 1982). Table 1 presents the basic physical and chemical characteristics for the OTCs most frequently detected in environmental matrices.

Among OT species, tributyltin (TBT), triphenyltin (TPhT) and their derivatives have been of particular concern because they were usually used as paint additives to prevent biofouling on ship hulls, marine platforms and fishing nets resulting in a world-wide pollution of aquatic environments (de Carvalho Oliveira et al., 2010). Table 2 gives an overview of OT product use patterns.

Table 1. Physical and chemical characteristics of selected OTCs (Adopted from Hoch, 2001).

\begin{tabular}{|c|c|c|c|c|}
\hline OTCs & Melting temperature $\left({ }^{\circ} \mathrm{C}\right)$ & Boiling Point $\left({ }^{\circ} \mathrm{C}\right)$ & Density $\left(\mathrm{g} \mathrm{cm}^{-3}\right)$ & Solubility (mg dm $\left.{ }^{-3}\right)$ \\
\hline $\mathrm{Bu}_{4} \mathrm{Sn}$ & -97 & $145 / 1.3 \mathrm{kPa}$ & 1.06 & n.i \\
\hline \multirow[t]{2}{*}{$\mathrm{Bu}_{3} \mathrm{SnCl}$} & -16 & $172 / 3.3 \mathrm{kPa}$ & 1.21 & $50^{b}$ \\
\hline & & & & $5-17^{c}$ \\
\hline \multirow[t]{2}{*}{$\mathrm{Bu}_{2} \mathrm{SnCl}_{2}$} & $39-41$ & $135 / 1.3 \mathrm{kPa}$ & $-d$ & $4-50^{b}$ \\
\hline & & & & $92^{+}$ \\
\hline $\mathrm{BuSnCl}_{3}$ & n.i. ${ }^{a}$ & $93 / 1.3 \mathrm{kPa}$ & 1.69 & n.i. \\
\hline $\mathrm{Me}_{3} \mathrm{SnCl}$ & $37-39$ & 154 & - & n.i. \\
\hline $\mathrm{Me}_{2} \mathrm{SnCl}_{2}$ & $106-108$ & $188-190$ & - & $20000^{b}$ \\
\hline $\mathrm{MeSnCl}_{3}$ & $48-51$ & 171 & - & n.i \\
\hline
\end{tabular}

${ }^{a}$ n.i. no information, ${ }^{b}$ solubility in sea water, ${ }^{c}$ solubility in distilled water, ${ }^{d}$ no data

Table 2. Main industrial applications of OTCs (Piver, 1973; Hoch et al., 2001; de Carvalho Oliveira, 2010)

\begin{tabular}{lll}
\hline $\begin{array}{c}\text { OTCs } \\
\text { production }\end{array}$ & \multicolumn{1}{c}{ Industrial applications } & OTCs \\
\hline \multirow{2}{*}{ Heat stabilizers } & Transformer oils stabilizers & tetraphenyl tin \\
\cline { 2 - 3 } & PVC stabilizer & $\begin{array}{l}\text { dibutyltin dilaurate; dibutyltin maleate; dibutyltin laureate-maleate; } \\
\text { dibutyltin bis (lauryl mercaptide); dibutyltin S, S-bis (isooctyl thioglycolate); } \\
\text { dibutyltin } \beta \text { - mercaptopropionate; di-n-octyltin maleate; di-n-octyltin S, S- } \\
\text { bis (isooctyl thioglycolate); di-n-octyltin } \beta \text { - mercaptopropionate. }\end{array}$ \\
\hline \multirow{2}{*}{ Catalysts } & Curing agent for silicone rubbers & dibutyltin dioctoate; dibutyltin dilaureate \\
\cline { 2 - 3 } & $\begin{array}{l}\text { Urethane and esterification } \\
\text { catalysts }\end{array}$ & $\begin{array}{l}\text { dibutyltin diacetate; dibutyltin dioctoate; dibutyltin dilaureate; dibutyltin } \\
\text { dilchloride; dibutyltin dilauryl mercaptide; dimethyltin dichloride; diethyltin } \\
\text { dioctoate; stannous octoate }\end{array}$ \\
\hline \multirow{2}{*}{ Biocides } & $\begin{array}{l}\text { Rodent repellant, mollusicide, } \\
\text { fungicide, algicide and insecticide }\end{array}$ & $\begin{array}{l}\text { tributyltin chloride; tributyltin acetate; triphenylltin chloride; triphenylltin } \\
\text { hydroxide; dibutyltin dilaurate }\end{array}$ \\
\cline { 2 - 3 } & $\begin{array}{l}\text { Preservatives for food, textile, } \\
\text { paper, leather and glass }\end{array}$ & bis(tributyltin) oxide; TBT0; tributyltin linoleate \\
\hline
\end{tabular}


Table 3. Same analytical methods for GC reported by different researchers for OTCs in marine-sediment samples (2005 - 2013). a) Homogenization, b) Extraction, c) Clean up.

\begin{tabular}{|c|c|c|c|c|c|c|}
\hline \multirow{2}{*}{$\begin{array}{l}\text { Derivatization } \\
\text { Methylation }\end{array}$} & \multirow[b]{2}{*}{$\begin{array}{l}\text { Sample treatment } \\
\text { a) } 0.05 \% \mathrm{w} / \mathrm{v} \text { tropolone solution in methanol - ultrasonic bath for } 15 \mathrm{~min} \text { and centrifugation } \\
\text { at } 4000 \mathrm{rpm} \text { for } 10 \mathrm{~min} \text { (repeated three times). } \\
\text { b) dichlorometane } \\
\text { c) n-hexane. }\end{array}$} & \multirow{2}{*}{ Detector } & \multicolumn{2}{|c|}{ LOD (ng/g) } & \multirow[b]{2}{*}{$\begin{array}{c}\text { Recovery (\%) } \\
- \\
82 \\
81\end{array}$} & \multirow{2}{*}{$\begin{array}{l}\text { References } \\
\text { Berto et al., } 2007\end{array}$} \\
\hline & & & $\begin{array}{l}\text { MBT } \\
\text { DBT } \\
\text { TBT }\end{array}$ & $\begin{array}{l}- \\
8 \\
4\end{array}$ & & \\
\hline \multirow[t]{7}{*}{ Ethylation } & $\begin{array}{l}\text { b) } 20 \% \mathrm{HCl} / \text { methanol solution (1:1) - ultrasonic bath for } 1 \mathrm{~h} \text { - centrifugation at } 3000 \mathrm{rpm} \text { for } \\
5 \mathrm{~min} \text { - adding of solution sodium acetate and heating at } 40^{\circ} \mathrm{C} \text { for } 15 \mathrm{~min} \text {. } \\
\text { c) SPME }\end{array}$ & FPD & $\begin{array}{l}\text { MBT } \\
\text { DBT } \\
\text { TBT }\end{array}$ & $\begin{array}{l}0.19 \\
0.09 \\
0.08\end{array}$ & $\begin{array}{c}116 \\
93 \\
122\end{array}$ & Wang et al., 2008 \\
\hline & $\begin{array}{l}\text { a) ascorbic acid with ethyl acetate - homogenization with } 1 \mathrm{~N} \mathrm{HBr} \text {-methanol/ethyl acetate } \\
(1: 1) \text { - centrifugation. } \\
\text { b) ethyl acetate/hexane ( } 3: 2) \text {, adding of hexane to separate water phase - concentration } \\
\text { near to dryness - solved into ethanol and mixed with } 1 \mathrm{M} \text { acetate buffer (pH 5.0). } \\
\text { c) Florisil Sep - Pak column - eluent: -. }\end{array}$ & MS & $\begin{array}{l}\text { MBT } \\
\text { DBT } \\
\text { TBT }\end{array}$ & $\begin{array}{l}1-5 \\
1-5 \\
1-5\end{array}$ & $\begin{array}{c}38 \\
38-123 \\
38-123\end{array}$ & Sousa et al., 2007 \\
\hline & $\begin{array}{l}\text { b) mixture of methanol, hexane and glacial acid. } \\
\text { c) de-actived aluminum oxide and C18 material - eluent n-hexane. }\end{array}$ & AED & $\begin{array}{l}\text { MBT } \\
\text { DBT } \\
\text { TBT }\end{array}$ & $\begin{array}{l}- \\
- \\
-\end{array}$ & $\begin{array}{l}- \\
- \\
-\end{array}$ & $\begin{array}{l}\text { Verslycke et al., } \\
\quad 2005\end{array}$ \\
\hline & b) acetic acid/methanol solution (3:1) - microwave $90 \mathrm{~W}$ for $4 \mathrm{~min}$ & ICP-MS & $\begin{array}{l}\text { MBT } \\
\text { DBT } \\
\text { TBT } \\
\end{array}$ & $\begin{array}{l}0.1 \\
0.1 \\
0.1 \\
\end{array}$ & $\begin{array}{l}- \\
- \\
-\end{array}$ & Üveges et al., 2007 \\
\hline & b) glacial acetic acid in methanol - mechanical stirring for $12 \mathrm{~h}$. & FPD & $\begin{array}{l}\text { MBT } \\
\text { DBT } \\
\text { TBT } \\
\end{array}$ & $\begin{array}{l}- \\
- \\
-\end{array}$ & $\begin{array}{l}- \\
- \\
-\end{array}$ & Mzoughi et al., 2005 \\
\hline & $\begin{array}{l}\text { b) acetone }+1 \mathrm{M} \mathrm{HCl} \text {-methanol/ethyl acetate }(1: 1) \text { shaked for } 10 \mathrm{~min} \\
\text { c) hexane + water shaked for } 10 \mathrm{~min} \text { - Florisil Sep-Pack column - eluent: diethyleterhexane }\end{array}$ & MS & $\begin{array}{l}\text { MBT } \\
\text { DBT } \\
\text { TBT } \\
\end{array}$ & $\begin{array}{l}1 \\
1 \\
1 \\
\end{array}$ & $\begin{array}{l}107 \\
108 \\
109 \\
\end{array}$ & Harino et al., 2007 \\
\hline & $\begin{array}{l}\text { a) } \mathrm{HCl} / \text { methanol }(1: 20, \mathrm{v} / \mathrm{v} \text { ) solution - vortex for } 1 \mathrm{~min} \text { - sonication for } 20 \mathrm{~min} \text { - centrifuged } \\
\text { at } 3000 \mathrm{rpm} \text { for } 5 \mathrm{~min} \text {. (repeated once) } \\
\text { b) Adding a buffer }(\mathrm{HAc} / \mathrm{NaAc}, \mathrm{pH} 5) \\
\text { c) SPME to the headspace of solution, stirred at } 750 \mathrm{r} \mathrm{min}^{-1} \text { under } 25^{\circ} \mathrm{C} \text { for } 15 \mathrm{~min}\end{array}$ & FPD & $\begin{array}{l}\text { MBT } \\
\text { DBT } \\
\text { TBT }\end{array}$ & $\begin{array}{l}3.6 \\
2.3 \\
0.7\end{array}$ & $\begin{array}{l}85.8 \\
94.2 \\
91.7\end{array}$ & Zhang et al., 2013 \\
\hline \multirow[t]{2}{*}{ Propylation } & $\begin{array}{l}\text { a) } 0.1 \% \text { tropolone-benzene and } 2 \mathrm{~N} \mathrm{HCl}-\text { centrifugation } \\
\text { b) } 0.1 \% \text { tropolone-benzene and dryed with } \mathrm{Na}_{2} \mathrm{SO}_{4} \text {. } \\
\text { c) Florisil-packed glass column - eluent: } n \text {-hexane. }\end{array}$ & FPD & $\begin{array}{l}\text { MBT } \\
\text { DBT } \\
\text { TBT }\end{array}$ & $\begin{array}{r}2.5 \\
2.7 \\
-\end{array}$ & $\begin{array}{l}85 \\
94 \\
92\end{array}$ & $\begin{array}{l}\text { Sudaryanto et al., } \\
\qquad 2005\end{array}$ \\
\hline & b) tropolone/benzene solution & FPD & $\begin{array}{l}\text { MBT } \\
\text { DBT } \\
\text { TBT }\end{array}$ & $\begin{array}{c}5 \\
1.5 \\
3.2\end{array}$ & $\begin{array}{l}85.6 \\
93.5 \\
92.4\end{array}$ & Liu et al., 2011 \\
\hline Pentylation & $\begin{array}{l}\text { b) toluene/HOAC (10:4) - sonication for } 5 \mathrm{~min} \text { - centrifugation at } 2000 \mathrm{rpm} \text { for } 3 \mathrm{~min} \text { - } \\
\text { (repeated twice). } \\
\text { c) Neutral allumina column }(3 \mathrm{~g}) \text { with anydrous } \mathrm{Na}_{2} \mathrm{SO}_{4} \text { - eluent: } \mathrm{n} \text {-hexane }\end{array}$ & FPD & $\begin{array}{l}\text { MBT } \\
\text { DBT } \\
\text { TBT }\end{array}$ & $\begin{array}{l}5 \\
5 \\
5\end{array}$ & $\begin{array}{l}- \\
- \\
-\end{array}$ & Diez et al., 2005 \\
\hline
\end{tabular}




\begin{tabular}{|c|c|c|c|c|c|c|}
\hline Derivatization & Sample treatment & \multirow[t]{2}{*}{ Detector } & \multicolumn{2}{|c|}{ LOD (ng/g) } & \multirow{2}{*}{$\begin{array}{c}\text { Recovery (\%) } \\
-\end{array}$} & \multirow{4}{*}{$\begin{array}{c}\text { References } \\
\text { Fernandez et al., } \\
2005\end{array}$} \\
\hline & b) toluene/acido acetico (10:4) solution - ultrasonic bath $125 \mathrm{~W}$ for $15 \mathrm{~min}-0.05 \%$ & & MBT & 4.5 & & \\
\hline & ammonium pyrrolidinedithiocarbamate APDC aqueous solution. (repeated three times). & \multirow[t]{2}{*}{ PFPD } & DBT & 4.5 & - & \\
\hline & c) $2 \%$ de-activated allumina and anhydrous $\mathrm{Na}_{2} \mathrm{SO}_{4}$ eluent: $n$-hexane. & & TBT & 5.9 & - & \\
\hline & a) water/HBr (1:1) & \multirow{3}{*}{ FPD } & MBT & 0.8 & - & \multirow{3}{*}{$\begin{array}{l}\text { Gomez-Ariza et al., } \\
2006\end{array}$} \\
\hline & b) $0.04 \% \mathrm{w} / \mathrm{v}$ tropolone solution in dichloromethane & & DBT & 0.8 & - & \\
\hline & c) Florisil column - eluent: penthane & & TBT & 0.8 & - & \\
\hline & a) $0.03 \%$ solution of tropolone in methanol and $\mathrm{HCl}-$ vortex for $1 \mathrm{~h}$. & \multirow{3}{*}{ MS } & MBT & 0.2 & 99 & \multirow{3}{*}{ Jadhav et al., 2009} \\
\hline & b) dichloromethane (repeated twice) & & DBT & 0.2 & 86 & \\
\hline & c) Actived silica gel - eluent: & & TBT & 0.2 & 96 & \\
\hline \multirow[t]{3}{*}{ Hexylation } & \multirow{3}{*}{$\begin{array}{l}\text { a) extraction cell with } \mathrm{n} \text {-hexane } 1 \mathrm{~mL} \mathrm{~min}-1 \text { - heating to } 60^{\circ} \mathrm{C} \text {. } \\
\text { b) } 100^{\circ} \mathrm{C} \text { and } 100 \mathrm{~atm} \text { for } 10 \mathrm{~min} \text { (repeated three times) }\end{array}$} & & MBT & - & - & \multirow{3}{*}{ Lee et al., 2006} \\
\hline & & MS & DBT & - & - & \\
\hline & & & TBT & 1.8 & $80.2-106.7$ & \\
\hline
\end{tabular}


Under favorable conditions, OTCs may degrade through successive dealkylation producing dibutyltin or diphenyltin (DBT or DPhT), monobutyltin ormonophenyltin (MBT or MPhT), and, ultimately, inorganic tin and becoming progressively less toxic in the process (NRCC, 1985).

\section{Analytical methods for OTCs in marine sediment}

In Fig. 2, the typical procedures used for the determination of OTCs in marine sediment are presented. In the first studies carried out on sediment, the butyltin concentrations were measured by hydride derivatization and atomic absorption (Stallard et al., 1987; Dowson et al., 1992).

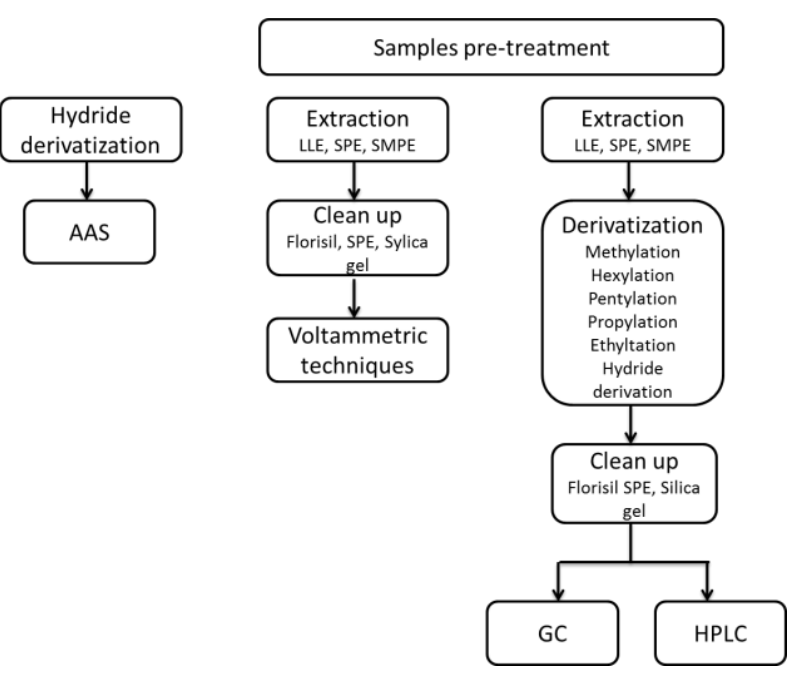

Figure 2. Typical procedures followed for the analysis of OTCs in marine sediment.

Nowadays species selective analysis of OTs is performed by coupled techniques based on the combination of chromatography separation with a sensitive and element selective detection method. The most common technique is gas chromatography (GC) coupled with element specific detection. Despite the need for thermally stable and volatile analytes GC has become the preferred sample introduction technique for the time resolved introduction of analytes into an atomic spectrometer because of the high resolution and sensitivity, the latter due to quasi $100 \%$ sample introduction efficiency and virtually no energy losses for the vaporization and desolvation of the mobile phases.

Table 3 provides summary information on the analytical methods applied by different researchers from 2005 up to the present and the analytical conditions used in each case as well as method validation results (recoveries and detection limits) obtained through GC analysis of marine sediment samples. Gas chromatography with mass spectrometry detection (GC-MS) in full scan and selective ion monitoring (SIM) modes has become a useful tool in organometallic compounds analysis because it offers simultaneous identification and quantitation of a large number of these compounds, including OTCs (MoscosoPérez et al., 2015).
The OTCs extraction is carried out with multi-step procedures such as liquid/liquid extraction (LLE), cryogenic trapping, supercritical fluid extraction or solid phase micro extraction (SPME) (Ochsenkühn et al., 2001). The SPME sampling can be carried out either in the direct mode (immersed in the liquid) or in the headspace (HS) mode (Moscoso-Pérez et al., 2015). Due the high volatility of OTCs in their alkylated forms, HS mode is the technique usually selected. Other procedures, also included in the group of green analytical pre-concentration procedures like SPME, have been applied to determine OTCs, e.g. stir bar sorptive extraction (SBSE) or liquid phase microextraction (LPME) (Moreda-Piñeiro et al., 2013). For most of the above-mentioned techniques usually an additional step, the derivatization of the OTCs to more volatile compounds are required, such as Grignard alkylation (Szpunar-Lobinska et al., 1995). Clean-up procedures are applied by many researchers in order to increase the sensitivity of the methods, usually by silica and florisil columns. In order to overcome the derivatization step, OTs can be converted into inorganic tin making possible the use of all techniques usually applied for metal determination as AAS, AVS, Inductive Coupled Plasma - Optical Emission Spectrometry (ICP - OES) and Inductive Coupled Plasma Mass Spectrometry (ICP - MS). Nevertheless in some cases AAS technique not allow to assess low tin concentrations, due to the complexity of the sediment matrix. Therefore, various voltammetric techniques have been attempted in the last years giving results accurate and reproducibile (Ochsenkühn et al., 2001). Although in some cases no differentiation of OTs can be achieved, the polarographic determination of the interfering species DPT and MPT, as well as DBT and TPT is possible through a double peak evaluation and a prior chromatographic separation and the detection limits for the determination of TBT, DBT, MPT, DPT and TPT can be improved to lower concentrations, when using ASV at a hanging mercury drop electrode (HMDE). By comparing the different techniques use to detect OTCs in sediment no significant difference could be observed in LOD. Dowson et al., (1992) used a modified version of the "purge and trap" boiling point separation method. OTs hydrides generated by the adding of $\mathrm{NaBH}_{4}$ to the sample were cryogenic trapped using liquid nitrogen. Hydride species were sequentially desorbed in relation to their specific boiling point after heating of the trap and were carried by helium flow into the quartz cell of AAS. TBT, DBT and MBT detection limits were reported around $1 \mathrm{ng} \mathrm{g}^{-1}$. According to Table 3, some GC methods present LOD higher than these values. The lowest LOD for TBT corresponding to $0.08 \mathrm{ng} \mathrm{g}^{-1}$ has been reported by Wang et al., (2008). On the other hand, no comparison could be carried out between "old" and "new" techniques in terms of recovery due to missing of data in papers published around 1980 applying hydride generation. Although traditional methods are considered time-consuming, also the sample preparation for GC analysis is an often-tedious step, involving much time and efforts in order to obtain a clear extract for low-levels OTCs analysis, and this is due to the complexity of sample matrix. Ultrasonic extraction appears to be the mostly preferred sample preparation 
method currently. The problem associated with GC include: i) the need for the extra equipment, e.g. a GC oven for temperature programmed runs and ii) the duration of analytical runs for OTCs detection (15-20 $\mathrm{min}$ ); the draw of large amount of solvents for the preparation and derivatization of the samples. Following the ongoing technological evolution in the laboratory equipment and consumables, the aim of tracing the OTCs residues in the marine sediment with higher precision and accuracy is being approached.

\section{Environmental concern}

The global concern about the environmental impact of OTCs on coastal ecosystems has been intensified after the first negative effects were reported in numerous studies (de Mora and Pelletier, 1997; Evans and Nicholson, 2000). Tributyltin is recognized worldwide as an endocrine disruptor, being associated with the imposex phenomenon on female dogwhelks and shell thickening on oysters during the 1980s (Lintelmann et al., 2003). Several scientists around the word are wondering if the total ban has been successful (Anastasiou et al., 2016; Batista et al., 2016; Filipkowska et al., 2016). Nevertheless, sixty-two years following their first application and 9 years after the complete ban on their use as biocides in 2003 (EC No. $782 / 2003)$, the negative impact of OTC seems still evident. In vitro studies suggest that TBT may cause immunotoxicity, teratotoxicity and neurotoxicity in mammals, including humans. Choi et al., (2013) measured the concentrations of butyltin compounds (BTs) in the livers of finless porpoises (Neophocaena asiaeorientalis) caught off the Korean coast in 2003 and 2010, to assess the effectiveness of legislative action against BTs. The concentrations of BTs ranged from 65.1 to 1432 (average: 370) $\mathrm{ng} / \mathrm{g}$ wet weight, within the ranges reported by previous studies. More recently, Anastasiou et al., (2016) reported high imposex frequency in Hexaplex trunculus and Nassarius nitidus collected from collected from the ports of Cagliari (Italy), El Kantaoui (Tunisia) and Olhão and Faro (Portugal), showing as in ports of Atlantic Ocean and Mediterranean Sea the contamination is still active. Imposex in gastropods (Acanthina monodon, Oliva peruviana and Xanthochorus cassidiformis) has been reported by Batista et al., (2016) in three areas along the central Chilean coast.

Filipkowska et al., (2016) analysed muscle and liver tissues of nine fish species reporting maximum total concentrations of butyltin compounds (BTs) of 715 and $1132 \mathrm{ng} \mathrm{g}^{-1} \mathrm{~d} . \mathrm{w}$. of $\mathrm{Sn}$, respectively. Results demonstrate that butyltins are still present in fish from the Polish coast of the Baltic Sea.

Finally, the contamination related to disposal of tributyltin (TBT) by contaminated harbour sediment, sewage sludge and/or biocide products has been raising concerns also for terrestrial environment and it may pose a risk to soil invertebrates and plants.

\section{Conclusions}

Marine sediment is a complex matrix where OTCs occur in concentration levels of $\mathrm{ng} / \mathrm{g}$, exhibiting toxic effects. In order to accurately quantify such levels of OTCs, increased analytical efforts and optimizations have been reported in the literature, regarding AAS, GC and HPLC. In conclusion, the increase of sensitivity and recovery of analytical methods for the determination of OTCs in marine sediment, still consists a challenge for researchers worldwide, although there has been a great progress regarding the capabilities of the analytical instrumentation available nowadays. Although TBT-based antifouling paints had been banned worldwide TBT pollution remains a serious environmental issue. The recent use and inputs associated to the lack of restrictions in some countries such as South America, where only Brazil and Uruguay are signatories of the IMO antifouling systems convention are contributing to this scenario.

\section{References}

Abalos M., Bayona J.M., Compa R., MercGranados C.L. and Prat M.D. (1997), Analytical procedures for the determination of organotin compounds in sediment and biota: a critical review, Journal of Chromatography A, 788, 1-49.

Anastasiou T.I., Chatzinikolaou E., Mandalakis M. and Arvanitidis C. (2016), Imposex and organotin compounds in ports of the Mediterranean and the Atlantic: Is the story over?, Science of the Total Environment, 569, 1315-1329.

Batista R.M., Castro I.B. and Fillmann G. (2016), Imposex and butyltin contamination still evident in Chile after TBT global ban, Science of the Total Environment, 566, 446-453.

Bayona Josep M. and Hoch M. (2001), Organotin compounds in the environment-An overview, Applied Geochemistry, 16, 719-743.

Berto D., Giani M., Boscolo R., Covelli S., Giovanardi O., Massironi M. and Grassia L. (2007), Organotins (TBT and DBT) in water, sediments, and gastropods of the southern Venice lagoon (Italy), Marine Pollution Bulletin, 55, 425-435.

Blundin S.J. and Chapman A.H. (1982), The environmental degradation of organotin compounds: A review, Environmental Technology Letters, 3, 267-272.

Choi M., An Y.R., Park K.J., Lee I.S., Hwang D.W., Kim J. and Moon H.B. (2013), Accumulation of butyltin compounds in finless porpoises (Neophocaena asiaeorientalis) from Korean coast: tracking the effectiveness of TBT regulation over time, Marine pollution bulletin, 66(1), 78-83.

de Carvalho Oliveira R. and Santelli R.E. (2010), Occurrence and chemical speciation analysis of organotin compounds in the environment: A review, Talanta, 82, 9-24.

De Mora S.J. and Pelletier E. (1997), Environmental tributyltin research: past, present, future, Environmental Technology, 18(12), 1169-1177.

Diez S., Lacortea S., Viana P. and Barceló D. (2005) Survey of organotin compounds in rivers and coastal environments in Portugal 1999 e 2000, Environmental Pollution, 136, 525-536.

Dowson P.H., Bubb J.M. and Lester J.N. (1992), Organotin distribution in sediments and waters of selected east coast estuaries in the UK, Marine Pollution Bulletin, 24, 492-498.

Evans S.M. and Nicholson G.J. (2000), The use of imposex to assess tributyltin contamination in coastal waters and open seas, Science of the Total Environment, 258(1), 73-80. 
Fernandez M.A., de Luca Rebello Wagener A., Limaverde A.M., Scofield A.L., Pinheiro F.M. and Rodrigues E. (2005), Imposex and surface sediment speciation: A combined approach to evaluate organotin contamination in Guanabara Bay, Marine Environmental Research, 59, 435-452.

Filipkowska A., Złoch I., Wawrzyniak-Wydrowska B. and Kowalewska G. (2016), Organotins in fish muscle and liver from the Polish coast of the Baltic Sea: Is the total ban successful?, Marine Pollution Bulletin, 111(1), 493-499.

Gomez-Ariza J.L., Santos M.M., Morales E., Giraldez I., SánchezRodas D., Vieira N., Kemp J.F., Boon J.P. and Ten-HallersTjabbes C.C. (2006), Organotin contamination in the Atlantic Ocean off the Iberian Peninsula in relation to shipping, Chemosphere, 64,1100-08.

Harino H., Yamamoto Y., Eguchi S., Kawai S., Kurokawa Y., Arai T., Ohji M., Okamura H. and Miyazaki N. (2007), Concentrations of Antifouling Biocides in Sediment and Mussel Samples Collected from Otsuchi Bay, Japan, Environmental Contamination and Toxicology, 52, 179-188.

Jadhav S., Bhosle N., Massaniss P. and Morabito R. (2009), Organotins in the sediments of the Zuari estuary, west coast of India, J. Environmental Management, 90, s4-s7.

Lee C.C., Hsieh C.Y. and Tien C.J. (2006), Factors influencing organotin distribution in different marine environmental compartments, and their potential health risk, Chemosphere, 65,547

Libralato G., Losso C., Arizzi Novelli A., Citron M., Della Sala S., Zanotto E., Cepak F. and Volpi Ghirardini A. (2008), Ecotoxicological evaluation of industrial Port of Venice (Italy) sediment samples after a decontamination treatment, Environmental Pollution, 156, 644-650. 10.1016/j.envpol.2008.06.025

Libralato G., Volpi Ghirardini A. and Avezzù F. (2010), How toxic is toxic? A proposal for wastewater toxicity hazard assessment, Ecotoxicology and Environmental Safety, 73, 1602-1611. doi: 10.1016/j.ecoenv.2010.03.007.

Lintelmann J., Katayama A., Kurihara N., Shore L. and Wenzel A. (2003), Endocrine disruptors in the environment (IUPAC Technical Report), Pure and Applied Chemistry, 75(5), 631-681.

Liu L.L., Wang J.T., Chung K.N., Leu M.Y. and Meng P.J. (2011), Distribution and accumulation of organotin species in seawater, sediments and organisms collected from a Taiwan mariculture area, Marine Pollution Bulletin, 63(5-12).

Lofrano G., Libralato G., Alfieri A. and Carotenuto M. (2016a), Metals and tributyltin sediment contamination along the Southeastern Tyrrhenian Sea coast, Chemosphere, 144, 399-407.

Lofrano G., Libralato G., Carotenuto M., Guida M., Inglese M., Siciliano A. and Meriç S. (2016b), Emerging Concern from Short-Term Leaching: A Preliminary Ecotoxicological Survey, 97, 646-652 DOI 10.1007/s00128-016-1937-x

Lofrano G., Libralato G., Minetto D., De Gisi S., Todaro F., Conte B., Calabrò D., Quatraro L. and Notarnicola M. (2017), In situ remediation of contaminated marine sediment: an overview, Environmental Science and Pollution Research, 24(6), 5189-5206. doi: 10.1007/s11356-016-8281-x.

Mamindy-Pajany Y., Libralato G., Roméo M., Hurel C., Losso C., Volpi Ghirardini A. and Marmier N. (2010), Ecotoxicological evaluation of Mediterranean dredged sediment ports based on elutriates with oyster embryotoxicity tests after composting process, Water Research, 44(6), 1986-1994. doi: 10.1016/j.watres.2009.11.056.

Moreda-Piñeiro A.J., Moreda-Piñeiro P., Bermejo-Barrera S. Bakirdere (Ed.), Speciation Studies in Soil, Sediment and Environmental Samples, Science Publishers Books Marketed \& Distributed by CRC Press (A Taylor \& Francis Group Co.), Enfiels, New Hampshire (EEUU) (2013), pp. 19-201

Moscoso-Pérez C., Fernández-González V., Moreda-Piñeiro J., López-Mahía P., Muniategui-Lorenzo S. and Prada-Rodríguez D. (2015), Determination of organotin compounds in waters by headspace solid phase microextraction gas chromatography triple quadrupole tandem mass spectrometry under the European Water Framework Directive, Journal of Chromatography A, 1385, 85-93.

Mzoughia N., Lespesb G., Bravo M., Dachraouic M. and PotinGautier M. (2005), Organotin speciation in Bizerte lagoon (Tunisia), Science of the Total Environment, 349, 211- 222.

NRCC (National Research Council of Canada). 1985. Organotin compounds in the aquatic environment: Scientific criteria for assessing their effects on environmental quality. NRCC Publ. No. 22494. Associate Committee on Scientific Criteria for Environmental Quality, Ottawa.

Ochsenkuehn K.M., Ochsenkuèhn-Petropoulou M., Tsopelas F. and Mendrinos L. (2001), Different Behavior of Organotin Compounds by Anodic Stripping Voltammetry and their Quantification after Partial Ion Exchange Separation, Mikrochimica Acta, 136, 129-135.

Piver W.T. (1973), Organotin Compounds: Industrial Applications and Biological Investigation, Environmental Health Perspectives, 61-79.

Scancar J., Zuliani T., Turk T. and Milacic R. (2007), Organotin compounds and selected metals in the marine environment of Northern Adriatic Sea, Environmental Monitoring and Assessment, 127, 271-282.

Sousa A., Matsudaira C., Takahashi S., Tanabe S. and Barroso C. (2007), Integrative assessment of organotin contamination in a southern European estuarine system (Ria de Aveiro, NW Portugal): tracking temporal trends in order to evaluate the effectiveness of the EU ban, Marine Pollution Bulletin, 54, 1645-1653.

Stallard M., Hodge V. and Goldberg E. (1987), TBT in California coastal waters monitoring and assessment, Environmental Monitoring and Assessment, 9, 195-220.

Sudaryanto A., Takahashi S., Iwata H., Tanabe S., Muchtar M. and Razak H. (2005), Organotin residues and the role of anthropogenic tin sources in the coastal marine environment of Indonesia, Marine Pollution Bulletin, 50, 208-236.

Szpunar-Lobinska J., Witte C., Lobinski R. and Adams F.C. (1995), Separation techniques in speciation analysis for organometallic species, Fresenius Journal of Analytical Chemistry, 351, 351-377.

Terlizzi A., Fraschetti S., Gianguzza P., Faimali M. and Boero F. (2001), Environmental impact of antifouling technologies: state of the art and perspectives, Aquatic Conservation, 11, 311-317.

Üveges M., Rodríguez-González P., García Alonso I.J., Sanz-Medel A. and Fodor P. (2007), Isotope dilution analysis mass spectrometry for the routine measurement of butyltin compounds in marine environmental and biological samples, Microchemical Journal, 85, 115-121. 
Verslyckea Tim A., Vethaakb A.D., Arijsa K. and Janssen C.R. (2005), Flame retardants, surfactants and organotins in sediment and mysid shrimp of the Scheldt estuary (The Netherlands), Environmental Pollution, 136, 19-31.

Wang X., Hong H., Zhao D. and Hong L. (2008), Environmental behavior of organotin compounds in the coastal environment of Xiamen, China, Marine Pollution Bulletin, 57, 419-424.

Zhang K.G., Shi J.B., He B., Xu W.H., Li X.D. and Jiang G.B. (2013), Organotin compounds in surface sediments from selected fishing ports along the Chinese coast, Chinese Science Bulletin, 58, 231-237. 